\title{
Insulin sensing by astrocytes is critical for normal thermogenesis and body temperature regulation
}

\author{
Iyad H Manaserh'1,2, Emily Maly¹, Marziyeh Jahromi1, Lakshmikanth Chikkamenahalli1, Joshua Park ${ }^{3}$ and \\ Jennifer Hill1,2
}

1Department of Physiology and Pharmacology, College of Medicine and Life Sciences, The University of Toledo, Toledo, Ohio, USA ${ }^{2}$ Center for Diabetes and Endocrine Research, College of Medicine and Life Sciences, The University of Toledo, Toledo, Ohio, USA

${ }^{3}$ Department of Neuroscience, College of Medicine and Life Sciences, The University of Toledo, Toledo, Ohio, USA

Correspondence should be addressed to J W Hill: JenniferW.Hill@utoledo.edu

\begin{abstract}
The important role of astrocytes in the central control of energy balance and glucose homeostasis has recently been recognized. Changes in thermoregulation can lead to metabolic dysregulation, but the role of astrocytes in this process is not yet clear. Therefore, we generated mice congenitally lacking insulin receptors (Ir) in astrocytes (IrKOGFAP mice) to investigate the involvement of astrocyte insulin signaling. IrKOGFAP mice displayed significantly lower energy expenditure and a strikingly lower basal and fasting body temperature. When exposed to cold, however, they were able to mount a thermogenic response. IrKOGFAP mice displayed sex differences in metabolic function and thermogenesis that may contribute to the development of obesity and type II diabetes as early as 2 months of age. While brown adipose tissue exhibited higher adipocyte size in both sexes, more apoptosis was seen in IrKOGFAP males. Less innervation and lower BAR3 expression levels were also observed in IrKOGFAP brown adipose tissue. These effects have not been reported in models of astrocyte Ir deletion in adulthood. In contrast, body weight and glucose regulatory defects phenocopied such models. These findings identify a novel role for astrocyte insulin signaling in the development of normal body temperature control and sympathetic activation of BAT. Targeting insulin signaling in astrocytes has the potential to serve as a novel target for increasing energy expenditure.
\end{abstract}

\author{
Key Words \\ - astrocytic insulin signaling \\ - body temperature \\ - systemic metabolism \\ B3-adrenergic signaling
}

\section{Introduction}

Neuronal circuits are influenced by surrounding astrocytes, critical members of the 'tripartite synapse' (Araque et al. 1999). Astrocytes exchange information with neurons, respond to synaptic activity, and regulate synaptic transmission through the release of gliotransmitters such as prostaglandins ( $\mathrm{Xu}$ et al. 2003, Perea et al. 2009, Shiow et al. 2017). Mounting evidence demonstrates the essential role of astrocytes in modulating homeostatic functions including body weight and glucose metabolism. Astrocytes that regulate hypothalamic metabolic circuits act as sensors to inhibit or promote food intake (Kim et al. 2014, Yang et al. 2015). Astrocyte signaling activation within the basal medial hypothalamus, for example, reduces the activity of agouti-related protein (AgRP)-positive neurons and therefore diminishes both basal and ghrelin-induced 
calorie intake (Yang et al. 2015). Targeting hypothalamic astrocytes with the marker glial fibrillary acidic protein (GFAP) demonstrates that astrocyte insulin signaling plays a role in the transport of glucose into the brain and thereby helps to suppress food intake during peripheral hyperglycemia (Garcia-Caceres et al. 2016). In addition, impaired leptin signaling in GFAP-positive astrocytes induces gliosis, increases food intake, and promotes obesity (Kim et al. 2014, Wang et al. 2015, Garcia-Caceres et al. 2016).

Energy expenditure through activity and heat generation is an important component of body weight regulation. Provided they have a sufficient caloric supply, mammals are able to maintain their body temperature in a cold environment by vasoconstriction to avoid heat loss from the extremities and by shivering to generate heat from skeletal muscles (Contreras et al. 2015). In addition, the activation of brown adipose tissue (BAT) generates heat through uncoupling protein-1 (UCP1), which uncouples the mitochondrial proton gradient to release energy in a process called adaptive or nonshivering thermogenesis (Oelkrug et al. 2015). The sympathetic nervous system (SNS) plays a large role in this process. The SNS activates BAT B3-adrenergic receptors causing higher UCP1 activity and UCP1 gene expression while increasing lipolysis in white adipose tissue (WAT) (Heeren \& Munzberg 2013). In human infants, the supraclavicular fat depots resemble canonical BAT observed in rodents (Lidell et al. 2013), but there is less BAT in adults and its cellular composition is more heterogeneous (Lidell et al. 2013). In addition to brown adipocytes, adult humans have UCP1-expressing 'beige' adipocytes interspersed in WAT (Schulz et al. 2011, Harms \& Seale 2013, Chechi et al. 2017). BAT and beige adipose tissues are activated by cold exposure, by high fat diets, and after meal consumption (Vosselman et al. 2013), a phenomenon known as postprandial thermogenesis.

Changes in thermoregulation can result in dysregulation of the systemic metabolism (Heeren \& Munzberg 2013). Indeed, mice with genetic deletion of UCP-1 exhibit obesity in the absence of thermal stress (Feldmann et al. 2009). BAT in adult humans also plays an important role in energy regulation and could be a potential target for the treatment of obesity (Virtanen et al. 2009, Lee et al. 2014). While the involvement of astrocytes in circuits that control energy intake is clear, little information is available on how astrocytes influence the activation of brown and beige adipose tissue. We, therefore, examined how rendering astrocytes insensitive to insulin might alter thermoregulation in response to metabolic and environmental challenges.

\section{Materials and methods}

\section{Animal and genotyping}

To create an astrocyte-specific deletion of $\operatorname{Ir}$ (IrKOGFAP mice), GFAP-Cre mice (C57Bl/J6) (Frederick National Laboratory for Cancer Research, Frederick, MD, USA) were crossed with $I r^{\text {loxp }}$ mice $(\mathrm{C} 57 \mathrm{Bl} / \mathrm{J} 6)$ in which exon 4 of the $I r$ gene was flanked by loxP sites (Könner et al. 2007). GFAP is the main intermediate filament protein in mature astrocytes and an important component of the cytoskeleton in astrocytes during development (Reeves et al. 1989). After GFAP-Cre homozygous Ir floxed mice were generated, we then paired them with homozygous Ir floxed carrying the tdTomato gene inserted into the $\mathrm{Gt}$ (ROSA)26Sor locus to serve as a reporter under the control of Cre recombinase expression (JAX \# 007909). This breeding scheme generated our control (lacking Cre) and experimental mice. I $r^{\text {loxp }}$ mice littermates lacking cre expression or GFAP-cre mice were used as controls; comparisons between Ir roxp mice and GFAP-Cre mice were also performed where specified. Mice were weaned on postnatal day (PND) 21 and genotyped by real-time PCR performed by Transnetyx, Inc. (Cordova, TN, USA). Mice were maintained on a $12 \mathrm{~h}$ light: $12 \mathrm{~h}$ darkness cycle at $22-24^{\circ} \mathrm{C}$ by the University of Toledo Department of Laboratory Animal Resources. All procedures were approved by the Institutional Animal Care and Use Committee (IACUC) of the University of Toledo College of Medicine and Life Sciences (Toledo, OH, USA). All experiments were performed in accord with the relevant guidelines and regulations described in the IACUCapproved protocol number 106448.

\section{Body composition}

Body weights of singly housed mice were measured bi-monthly from 1 to 9 months of age for $I r^{\text {loxp }}$ and $I r K \mathrm{O}^{\text {GFAP }}$ groups and weekly from 3 to 10 weeks for $I r^{\text {loxp }}$ and Cre control groups. Body composition was measured at 2 and 7 months of age using NMR (minispec mq7.5; BurkerOptics, Billerica, MA, USA).

\section{Glucose and insulin tolerance tests}

GTTs and ITTs were performed as previously described (Heinrich et al. 2016). For GTTs, 2-month-old mice were fasted for $6 \mathrm{~h}$ and then given a dextrose injection $(2 \mathrm{~g} / \mathrm{kg}$ intraperitoneal (IP)). Tail blood glucose was then measured using a glucometer (AlphaTRAK; Abbot Laboratories) at 
$0,15,30,45,60,90$ and 120 min after injection. For ITTs, mice were fasted for 3-4 $\mathrm{h}$ and then injected with recombinant insulin (0.75 U/kg IP). Tail blood glucose was measured at the same time points as the GTT. GTT and ITT testing was repeated at 7 months of age. For quantitative analysis, area under curve (AUC) measurements were calculated for each animal in the control and experimental groups.

\section{Homeostasis model assessment of insulin resistance (HOMA IR)}

At 7-8 months of age, fasting serum was collected, glucose levels were recorded, and insulin levels were measured using an ELISA kit with intra-assay precision $\mathrm{CV} \leq 10.0 \%$ (Crystal Chem, Cat\# 90080) and sensitivity of $0.05 \mathrm{ng} / \mathrm{mL}$. The HOMA IR was calculated (fasting serum glucose $\times$ fasting serum insulin/22.5) to assess insulin resistance (Fraulob et al. 2010).

\section{Tissue collection}

Mice were terminated via an IP ketamine/xylazine injection to induce deep anesthesia followed by exsanguination. Liver, gonadal WAT, and interscapular BAT were then collected for gene expression and immunohistochemical staining. For liver and interscapular brown adipose histology, 7-8 months old mice (liver staining) or 9-month-old mice (interscapular brown adipose staining) were perfused with $10 \%$ formalin after ketamine/xylazine injection. Tissues were post-fixed overnight and then transferred to $70 \%$ ETOH until sectioning.

\section{Liver histology}

Liver tissue was paraffin embedded, sectioned, and stained with H\&E (Qiu et al. 2013) and ORO (Mehlem et al. 2013). An Olympus BX61US microscope (X-cite 120 LED boost EXCELITAS technology) with OlyVIA 2.9 software was used to visualize the staining. Liver sections were analyzed by evaluating lipid accumulation and inflammation via fat droplet counts and inflammatory gene expression levels. Liver sections were automatically analyzed by evaluating the number of fat droplets via ImageJ software (size (pixel^2) was set from 50 to infinity and circularity was set from 0.2 to 1.00 ).

\section{Polymerase chain reaction (PCR) gel electrophoresis}

DNA was extracted from control and experimental groups, using the QIAamp DNA Kit (Cat \#: 51304) for
$25 \mathrm{mg}$ of each tissue sample. PCR was performed for the insulin receptor (Ir) for all DNA samples using forward (5' AAATGACGGGGTGAGGGAAC 3') and reverse (5' GGCCGTGAAAgTtAAGAGGGG 3') primers. The PCR reaction was carried out in a $20 \mu \mathrm{L}$ volume, with $100 \eta g$ extracted DNA, $0.5 \mu \mathrm{M}$ of each primer, and $2 \mathrm{X}$ Hot-Start Taq Mastermix, (Denville's, Thermo Scientific). The temperature profile was one cycle of $95^{\circ} \mathrm{C}$ for $5 \mathrm{~min}$ (primary denaturation), followed by 35 cycles of $95^{\circ} \mathrm{C}$ for $30 \mathrm{~s}$ (denaturation), $60^{\circ} \mathrm{C}$ for $30 \mathrm{~s}$ (annealing), and $72^{\circ} \mathrm{C}$ for $40 \mathrm{~s}$ (extension), and a final extension $72^{\circ} \mathrm{C}$ for 5 min (Mikaeili et al. 2013). The extracted DNAs and PCR products of each method were loaded on separate $2 \%$ TAE agarose gels. The gels contained $0.5 \mu \mathrm{g} / \mathrm{mL}$ ethidium bromide for staining. Electrophoresis was carried out for $90 \mathrm{~min}$ at $80 \mathrm{~V}$. The bands were visualized in UV illuminator and digitally photographed.

\section{Gene expression analysis}

An RNeasy Lipid Tissue Mini Kit (Qiagen) permitted total RNA extraction. We synthesized single strand cDNA using a high capacity cDNA RT Kit (Applied Biosystems) (Solanki et al. 2017). In brief, mice were killed via lethal ketamine/xylazine injections and tissues were removed. In total, $100 \mathrm{mg}$ of dissected tissues were transferred into $1 \mathrm{~mL}$ of Trizol. The samples were then disrupted using a bead homogenizer. Chloroform was added and the samples were vigorously shaken and incubated at room temperature for $5 \mathrm{~min}$. A series of centrifugation steps were then performed and purified RNA was collected. RNA sample concentration was measured using a NanoDrop ${ }^{\mathrm{TM}}$ One/OneC Microvolume UV-Vis Spectrophotometer (Thermofisher Scientific). cDNA was synthesized with random primers and reverse transcriptase (Applied Biosystems) using $1 \mu \mathrm{g}$ of total RNA. cDNA was evaluated with quantitative RTPCR using True Amp SYBR green qPCR Supermix (Applied Biosystems). The relative amount of mRNA was calculated by comparison to the corresponding controls and normalized relative to glyceraldehyde 3-phosphate dehydrogenase (GAPDH). Data are presented as means \pm s.E. relative to $I r^{\text {loxp }}$ controls (relative quantitation $\left(\mathrm{RQ}=2^{-\Delta \Delta \mathrm{Ct})}\right)$. The sequences of the primers used are as follows: Tnfa; (F: CAGGCGGTGCCTATGTCTC; R: CGATCACCCCGAAGTTCAGTAG), Il10; (F: GCTGGA CAACATACTGCTAACC, R: ATT TCC GAT AAG GCT TGG CAA), Lxra; (F: AAACTGAAGCGGCAAGAAGA; R: GCAGGA CTTGAGGAGGTGAG), Ucp1; (F: GGATGGTGAACC CGACAACT, R: AACTCCGGCTGAGAAGATCTTG), BAr3; (F: GGCACAGGAATGCCACTCCAAT, 
R: AgGAgGgGAAGgtagAAGGAGAC), Chop; (F: AAG CCTGGTATGAGGATCTGC; R: TTCCTGGGGATGAGA TATAGGTG), Bcl2 homologous antagonist killer (Bak); (F: GCCCTGTACGTCTACCAGC; R: TGGCGATGTAATGAT GCAGTATG), Bclxl; (F: GGTGAGTCGGATTGCAAGTT, R: TGGATCCAAGGCTCTAGGTG), Gapdh; (F: AGGTCG GTGTGAACGGATTTG; R: TGTAGACCATGTAGT TGAGGTCA).

\section{Indirect calorimetry analysis}

Seven to 8-month-old mice were placed in calorimetric chambers (CLAMS system, Columbus Instruments, Columbus, OH, USA), acclimated for 2 days and then recorded for 3 days with free access to food and water as described (Ghadieh et al. 2015). Locomotor and physical activities were detected via an optical beam measuring vertical and horizontal movements. $\mathrm{O}_{2}$ consumption $\left(\mathrm{VO}_{2}\right), \mathrm{CO}_{2}$ production and energy expenditure were measured every $20 \mathrm{~min}$. The bar graphs show indirect calorimetry parameters $\left(\mathrm{VO}_{2}, \mathrm{VCO} 2, \mathrm{RER}\right.$, etc.) over the 72 -h period. In total, there are 864 individual points per group with each individual point representing the value of a 20-min interval ( 3 individual points per $\mathrm{h} \times 72 \mathrm{~h} \times 4$ mice per group $=864)$. Data are reported as mean \pm s.E.M. of light (06:00-18:00 h) and darkness (18:00-06:00 h) cycles (Ghadieh et al. 2015).

\section{Body temperature assessment}

At 9 months of age, body temperature measurements were obtained using a rectal temperature probe thermometer (Thermalert TH.5, Physitemp, Clifton, NJ, USA) between 9:00 and 10:00 $\mathrm{h}$ in the light cycle and 21:00 and 22:00 $\mathrm{h}$ in the darkness cycle, as described (Chong et al. 2015). As specified, baseline readings were obtained from mice with ad libitum access to food and water or following a 12-16-h overnight fast.

In the acute cold challenge, we fasted mice overnight and then individually caged them with bedding in a $4^{\circ} \mathrm{C}$ cold room for $80 \mathrm{~min}$. Body temperature was recorded every 20 min (Chong et al. 2015) and food was given when the mice were returned to standard temperatures.

\section{BAT histology and immunohistochemistry}

Paraffin-embedded BAT tissues were sectioned for staining with H\&E (Qiu et al. 2013) or a primary antibody; rabbit anti-TH (Abcam, ab112), rabbit anti-beta 3 adrenergic receptor (Abcam, ab94506); and a biotinylated goat anti-rabbit IgG secondary antibody (Vector lab, BA-1000). Immunohistochemical staining was performed as previously described (Nobili et al. 2017). Sections were photographed using an Olympus BX61US microscope (X-cite 120 LED boost EXCELITAS technology) with OlyVIA 2.9 software. For H\&E staining, BAT sections were automatically analyzed by evaluating the size and number of fat droplets via ImageJ software. Images were thresholded using the default setting and size (pixel^2) was set from 50 to infinity and circularity was set from 0.2 to 1.00 . For tyrosine hydroxylase $(\mathrm{TH})$ staining, nerve terminals were counted manually at 40× using OlyVIA 2.9 software. For beta 3 adrenergic receptor (BAR3) staining, a score was then giving in a range from 1 (lowest BAr3 expression intensity) to 5 (highest expression intensity). For TH staining and beta 3 adrenergic receptor (BAr3) staining, images obtained from OlyVIA 2.9 software were evaluated in a blinded manner by three qualified scientists.

\section{Statistical analysis}

All values in the text and figures are presented as mean \pm s.e.m. of independent experiments for the given $n$-sizes. Statistical significance was determined by two-way ANOVA with Tukey post-hoc test or three-way ANOVA with repeated measures followed by Tukey post-hoc test. For all statistical tests, a $P$ value of $<0.05$ was considered significant. Analyses were performed using GraphPad Prism 8 software (Graph Pad).

\section{Results}

To create an astrocyte-specific deletion of the $\operatorname{Ir}$ (IrKOGFAP mice), Irloxp mice were crossed with a mouse line expressing GFAP promotor-driven cre-recombinase (Könner et al. 2007). In mature astroglia, GFAP is the core intermediate filament protein; it is also an important element of their cytoskeleton during development (Reeves et al. 1989, Middeldorp \& Hol 2011). Thus, these mice lack Ir in GFAP-expressing cells throughout life. First, we established that the GFAP-cre mouse line alone shows no significant difference in body composition and systemic metabolism when compared to Ir ${ }^{\text {loxp }}$ mice (Supplementary Fig. 1B, C, D, E, F, G and H, see section on supplementary materials given at the end of this article). We have previously characterized the specificity of this deletion (Manaserh et al. 2019). Western blotting confirmed lower $I r$ protein levels in the brains of IrKOGFAP mice 
(Manaserh et al. 2019). When crossed with a cre-dependent tdTomato red fluorescent protein (RFP) reporter line, RPF was observed in IrKOGFAP astrocytes (Manaserh et al. 2019); 94\% of GFAP immunopositive cells were found to show RFP staining. However, there was no localization with RFP when neurons were labeled with the neuronal marker NeuN (Manaserh et al. 2019). By using the astrocyte cell surface antigen-1 (ACSA-1) for fluorescenceactivated cell sorting (FACS), we isolated astrocytes from IrKOGFAP mice that exhibited substantially lower $I r$ mRNA levels when compared to astrocytes from control animals and non-astrocyte pools of cells (Manaserh et al. 2019). Gene expression of neuronal (Map1), tanycytic (Hes1 and Hes5), microglia (Cd11b), and endothelial (Vwf) markers were also measured in the astrocyte pool isolated by FACS, which confirmed the purity and specificity of these astrocytes. To further validate the specificity of our model, we tested $I r$ expression in peripheral tissues related to thermoregulation including liver, BAT, and WAT via PCR (Supplementary Fig. 1A). Finally, we used magnetic cell sorting to isolate astrocytes expressing the NA+-dependent glutamate transporter (GLT-1). Western blotting of this population demonstrated that prostaglandin $\mathrm{E}_{2}\left(\mathrm{PGE}_{2}\right)$ synthase levels were lower only in astrocytes from IrKOGFAP mice (Manaserh et al. 2019). Thus, multiple sources of evidence demonstrate that this line of mice exhibit a specific deletion of the $I r$ in astrocytes.
Using this model, we first examined energy balance and glucose regulation. There were no significant differences in mean bodyweight between IrKOGFAP and Ir ${ }^{\mathrm{lxop}}$ mice at each age considered (Supplementary Fig. 2A and B). IrKOGFAP and $I r^{\text {loxp }}$ groups also showed comparable fat and lean mass percentages at 2 months of age, but higher fat mass and lower lean mass percentages were observed in $I r \mathrm{KO}^{\mathrm{GFAP}}$ females at 7 months of age (Supplementary Fig. 2C and D). Insulin tolerance testing (ITT) revealed sex differences where IrKOGFAP male mice developed insulin resistance starting as early as 2 months. Insulin resistance was also confirmed at 7 months of age in IrKOGFAP male mice (Fig. 1A). Unlike males, congenital deletion of astrocyte $I r$ in female mice led to glucose intolerance at 7 months of age (Fig. 1D, E and F). In contrast, we found that the GFAP-cre only mouse line has a phenotype similar to Irloxp mice (Supplementary Fig. 1E, F, G and H). IrKOGFAP mice exhibited comparable fasting insulin and glucose levels at 7-8 months of age (Supplementary Fig. $3 \mathrm{~A}, \mathrm{~B}$ and $\mathrm{C}$ ).

At 7-8 months of age, IrKOGFAP mice showed comparable locomotion and food intake to control animals (Supplementary Fig. 4A, B, C, D, F and $\mathrm{G})$. Interestingly, more lipid droplets were seen in their livers (Fig. 2A, B and F) along with higher proinflammatory Tnfa gene expression in IrKOGFAP females, lower anti-inflammatory Il10 mRNA in IrKOGFAP males,

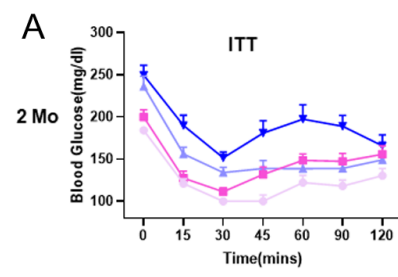

B

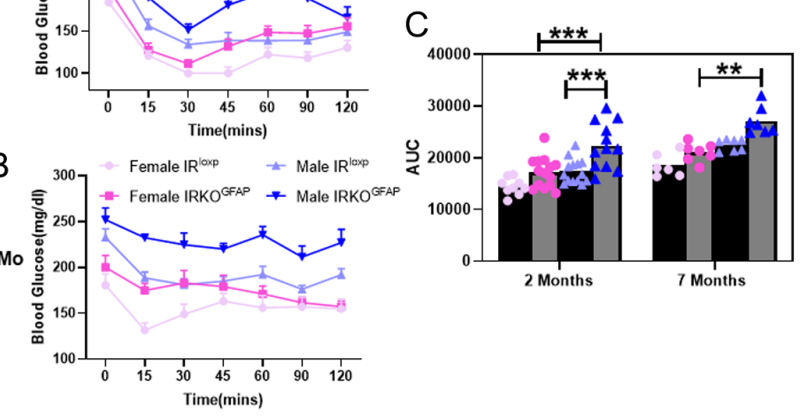

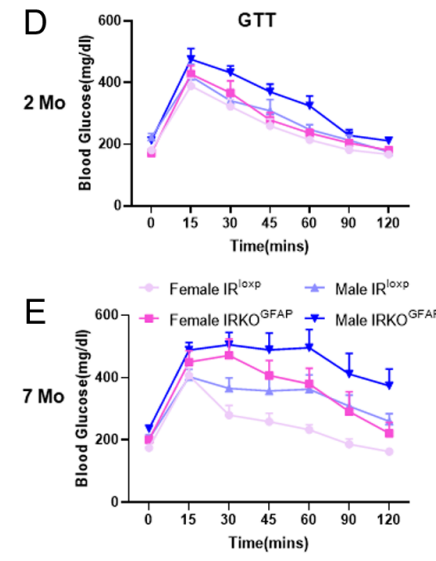

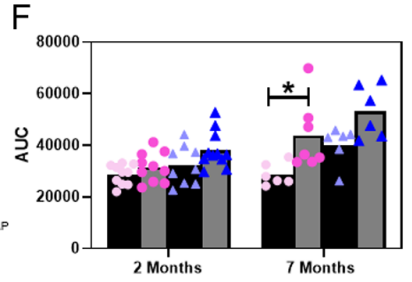

\section{Figure 1}

IrKOGFAP mice exhibit sex differences in insulin sensitivity and glucose tolerance over time. (A) Insulin tolerance test (ITT) measurements of blood glucose levels for females ( $n=9-14$ per group) and males ( $n=9-13$ per group) after peripheral insulin injections (0.75 U/kg IP) at 2 months of age. (B) ITT measurements of blood glucose levels for females ( $n=6-8$ per group) and males ( $n=7$ per group) after peripheral insulin injections at 7 months of age. (C) Area under curve (AUC) measurements of ITT for females and males at 2 months and 7 months of age. (D) Glucose tolerance test (GTT) measurements of blood glucose levels for females ( $n=10$ per group) and males ( $n=9-11$ per group) after peripheral glucose injection ( 2 g/kg) at 2 months of age. (E) GTT measurements of blood glucose levels for females ( $n=6-8$ per group) and males ( $n=7$ per group) after peripheral glucose injection at 7 months of age. (F) Area under curve (AUC) measurements of GTT for females and males at 2 months and 7 months of age. The female $/ r^{\text {roxp }}$ group is represented with light pink line/dots, female IrKOGFAP group with dark pink line/dots, male Irloxp group with light blue line/dots and male IrKOGFAP group with dark blue line/dots. Values are expressed as means \pm S.E.M. ${ }^{*} P<0.0332, * * P<0.0021,{ }^{*} * *<0.0002, * \star * * P<0.0001$ by three-way ANOVA and Tukey post-hoc test relative to IrKOGFAP vs Irloxp groups. 
A

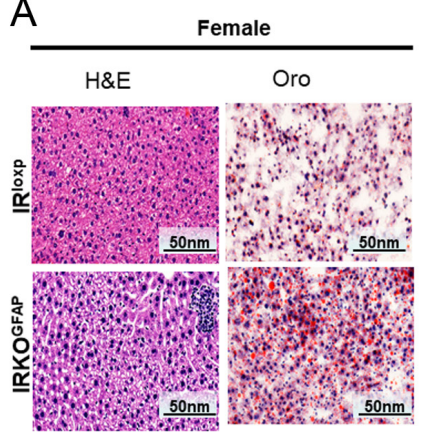

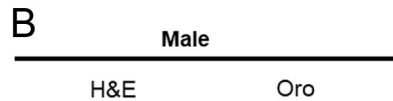

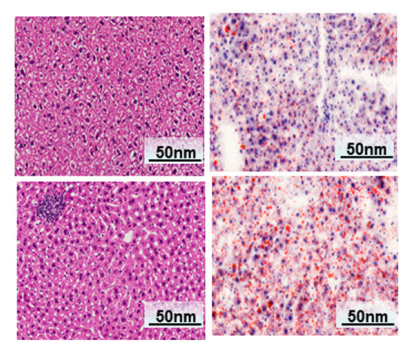

C
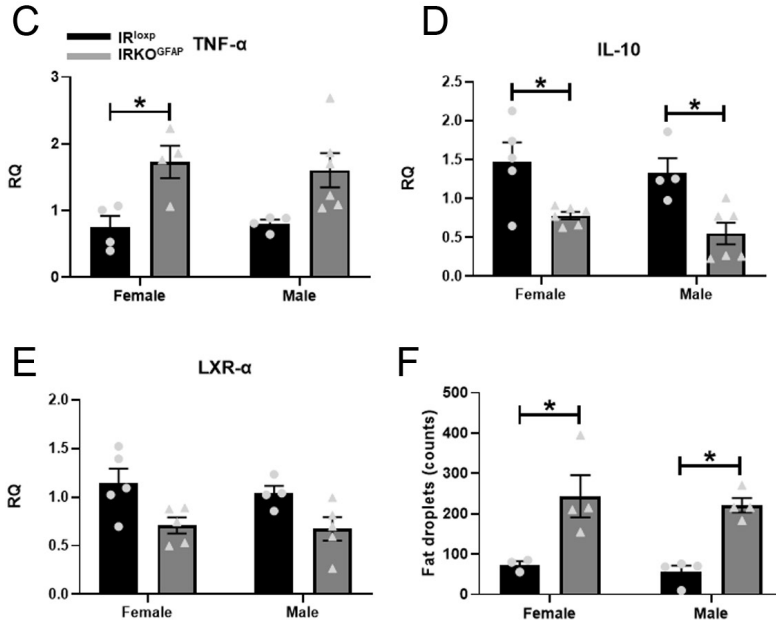

$\mathrm{F}$

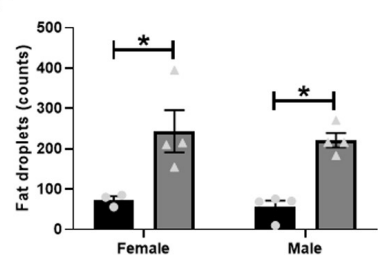

Figure 2

IrKOGFAP mice exhibit alterations in liver morphology and inflammation at 7-8 months of age. (A and B) Histological H\&E and ORO analysis of liver sections in females ( $n=3-4$ per group) and males ( $n=4$ per group). (C) Quantification of RT-PCR data showing fold change (RQ $\left.=2^{-\Delta \Delta C t}\right)$ in Tnfa mRNA expression in female and male mice $(n=4$ for females and $4-6$ for males). (D) Quantification of RT-PCR data showing fold change in //10 mRNA levels in females and males ( $n=4-5$ for females and 4-6 for males). (E) Quantification of RT-PCR data showing fold change in $L x r a$ mRNA expression in females and males ( $n=5$ for females and 4-5 for males). (F) Quantitative analysis of fat droplets in liver tissues of female and males mice ( $n=3$ per group). Female Irloxp group is represented with black bar/circle dots, female IrKOGFAP group with dark grey bar/triangle dots, male Irloxp group with black bar/circle dots and male IrKOGFAP group with dark grey bar/triangle dots. Values are expressed as means \pm S.E.M. $\star P<0.0332, * * P<0.0021, * * * P<0.0002, * * * * P<0.0001$ by two-way ANOVA and Tukey post-hoc test relative to IrKOGFAP vs / $r^{\text {loxp }}$ groups.

and comparable expression of the cholesterol transport marker Lxra gene in the liver of both sexes (Fig. 2C, D and E). Notably, I $r$ KOGFAP female mice also displayed lower $\mathrm{O}_{2}$ consumption $\left(\mathrm{VO}_{2}\right)$ (Fig. $3 \mathrm{~A}$ and $\mathrm{B}$ ) and had an elevated respiratory exchange ratio (RER), indicating that they utilize less fat for energy production (Fig. 3E). Unlike females, IrKOGFAP male mice exhibited lower $\mathrm{VO} 2, \mathrm{CO}_{2}$ production $\left(\mathrm{VCO}_{2}\right)$ and RER compared to controls (Fig. 3A, B, C, D and E).

The energy expenditure of male IrKOGFAP mice was lower in IrKOGFAP males (Fig. 4A and B), suggesting less
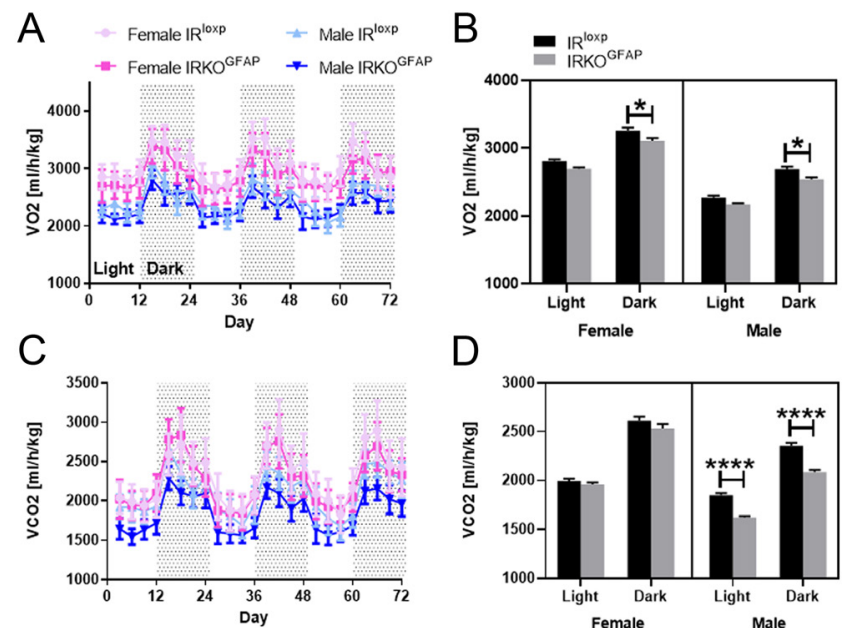

D

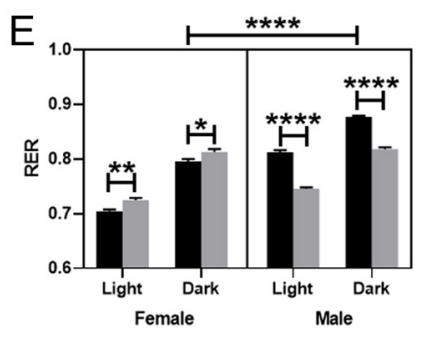

Figure 3

At 7-8 months of age, IrKOGFAP mice display significant sex differences in energy utilization. IrKOGFAP mice were fed ad libitum and subjected to indirect calorimetry analysis to assess light and darkness cycle of (A) $\mathrm{O}_{2}$ consumption in females and males, (B) carbon dioxide production $\left(\mathrm{VCO}_{2}\right)$ in females and males and (C) respiratory exchange ratio (RER) in female and male mice. Values represent measurements of 3 consecutive days. $n=4$ per group. The female Irloxp group is represented with a light pink line/black bar, the female IrKOGFAP group with a dark pink line/grey bar, the male /roxp group with a light blue line/black bar and the male IrKOGFAP group with a dark blue line/grey bar. Values are expressed as means \pm S.E.M. $* P<0.0332, * \star P<0.0021, * * \star P<0.0002, * * * * P<0.0001$ by three-way ANOVA and Tukey post-hoc test relative to IrKOGFAP vs Irloxp groups.

thermogenesis. Indeed, in the fed state, IrKOGFAP mice exhibited lower body temperature in the darkness phase (female $33.62 \pm 0.2662$, male $33.18 \pm 0.2418$ ) when compared to the $I r^{\text {loxp }}$ group (female $36.76 \pm 0.1647$, male $36.61 \pm 0.2029$ ) (Fig. 4C). After an overnight fast, IrKOGFAP mice displayed a substantially lower body temperature in the light phase (female $32.92 \pm 0.4120$, male $32.61 \pm 0.1184$ ) when compared to controls (female $35.88 \pm 0.2833$, male $34.66 \pm 0.2534$ ) (Fig. 4D). We next tested whether IrKOGFap mice were able to defend their body temperature during an acute cold temperature challenge. Although $I r \mathrm{KO}^{\mathrm{GFAP}}$ mice exhibited a lower body temperature at 0 and $20 \mathrm{~min}$, body temperatures at 40 , 60 and $80 \mathrm{~min}$ of the cold challenge did not differ from controls (Fig. 4E). 

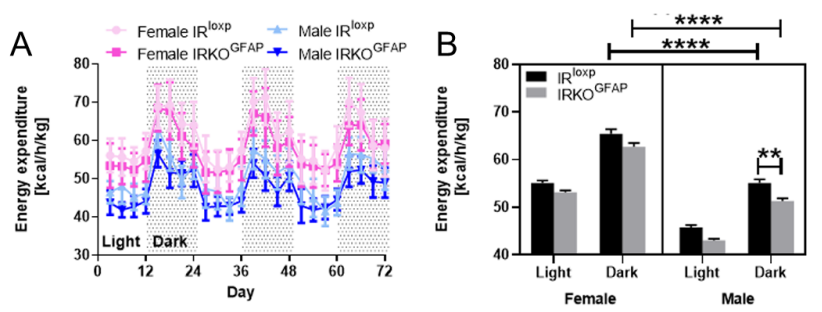

Fed state
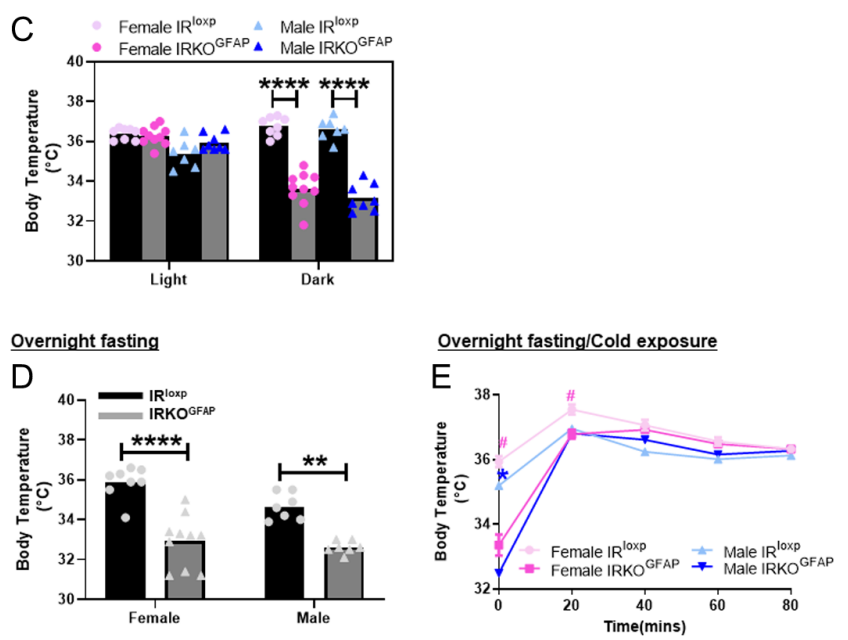

\section{Figure 4}

Despite sex differences in energy expenditure, IrKOGFAP mice display a significant reduction in body temperature at 9 months of age. IrKOGFAP mice were fed ad libitum and subjected to indirect calorimetry analysis to assess light and darkness cycle of (A) energy expenditure for 3 consecutive days for female and male mice ( $n=4$ per group). Recording of body temperature measurements via rectal probe in females and males during (B) fed state, (C) overnight fasting, and (D) overnight fasting/ cold exposure condition. $n=8-10$ per group for females, $n=7-8$ per group for males. The female Irloxp group is represented with a light pink line/black bar, the female IrKOGFAP group with a dark pink line/grey bar, the male Irloxp group with a light blue line/black bar and the male IrKOGFAP group with a dark blue line/grey bar. Values are expressed as means \pm S.E.M. $* P<0.0332, * \star P<0.0021, * \star \star P<0.0002, * \star \star \star P<0.0001$ by two-way ANOVA and Tukey post-hoc test (panel D) and three-way ANOVA and Tukey post-hoc test relative to IrKOGFAP vs Irloxp groups.

IrKOGFAP female mice showed larger fat droplets and a lower number of adipocytes in BAT (Fig. 5A, C and D). Similar results were seen in males (Fig. 5B, C and D). IrKOGFAP mice displayed lower Ucp1 mRNA levels in females with a similar trend in males (Fig. 6A), suggesting less SNS outflow. Lower SNS input to BAT may increase apoptosis of adipocytes (Penicaud et al. 2000). Indeed, we found higher pro-apoptotic markers C/EBP homologous protein (Chop) and Bcl-2 homologous antagonist/killer (Bak) mRNA levels (Fig. 6C and D) and less anti-apoptotic marker B-cell lymphoma-extra-large mRNA (Bclxl) in IrKOGFAP female mice (Fig. 6E).

Tyrosine hydroxylase (TH) is a rate limiting enzyme for catecholamine biosynthesis that serves as a marker of

(C) 2020 Society for Endocrinology Published by Bioscientifica Ltd. Printed in Great Britain
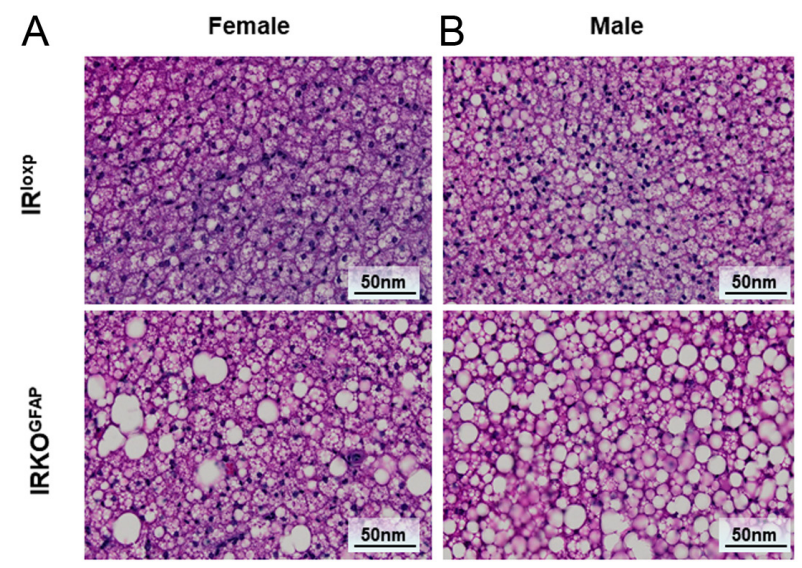

C

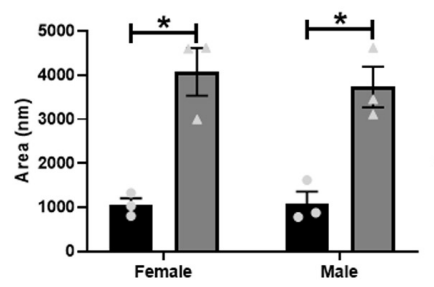

D

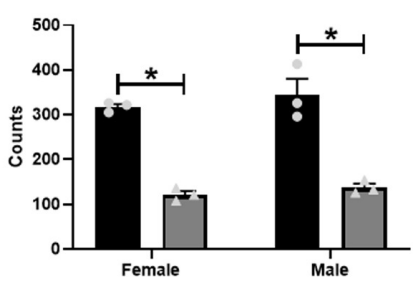

Figure 5

IrKOGFAP mice show alterations in BAT morphology and larger droplet size at 9 months of age. (A and B) Histological H\&E analysis in females and males. (C) Quantitative analysis of fat droplet area in female and male mice. (D) Quantification of BAT cell counts in females and males. $n=3$ per group. Female /rloxp group is represented with black bar/circle dots, female IrKOGFAP group with dark grey bar/triangle dots, male /rloxp group with black bar/circle dots and male IrKOGFAP group with dark grey bar/ triangle dots. Values are expressed as means \pm S.E.M. ${ }^{*} P<0.0332$,

$* * P<0.0021, * * * P<0.0002, * * * * P<0.0001$ by two-way ANOVA and Tukey post-hoc test relative to IrKOGFAP vs Irloxp groups.

denervation (Daubner et al. 2011). IrKOGFAP mice had fewer TH positive nerve endings $(119.3 \pm 9.735)$ in BAT when compared to controls (523.3 \pm 26.03$)$ (Fig. 7A, C and D). We then determined the levels of B3-adrenergic receptor (BAR3), a G-protein coupled receptor that increases UCP1 levels (Fig. 8). In addition to lower BAR3 mRNA levels in IrKOGFAP females (Fig. 6B), both IrKO ${ }^{\text {GFAP }}$ female and male mice had lower protein levels of BAR3 (Fig. 8A, B and C). These results suggest that insulin resistance in astrocytes alters SNS outflow to BAT. All outlier data points have been included in the main statistical analysis.

\section{Discussion}

Maintaining a constant body temperature requires a substantial amount of energy. Therefore, sensing energy availability is a critical function of thermoregulatory circuits. The hormone insulin is one of several metabolic signals that regulate the decision whether to defend 

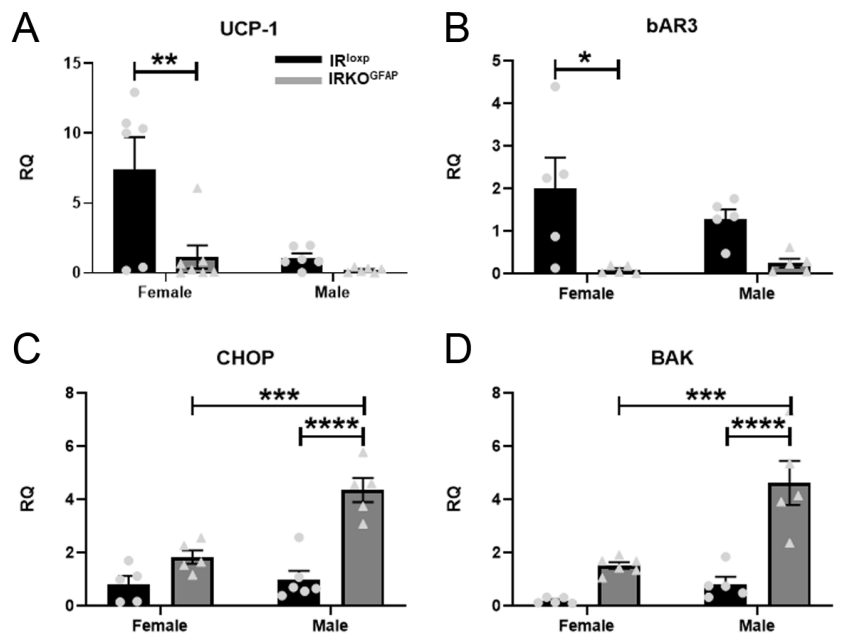

C
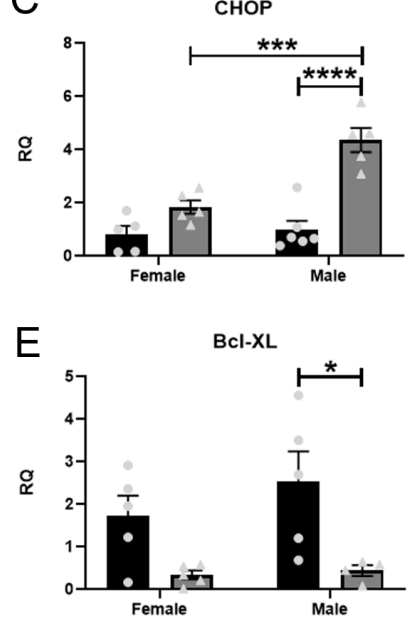

Figure 6

At 9 months of age, IrKOGFAP BAT exhibit sex differences in gene expression that are consistent with lower thermogenesis and higher apoptosis. Quantification of RT-PCR data showing fold change $(R Q=2-\Delta \Delta C t)$ in (A) Ucp1 mRNA levels, (B) BAR3 mRNA levels, (C) pro-apoptotic marker Chop mRNA levels, (D) pro-apoptotic Bak mRNA levels, and (E) antiapoptotic $B c / x /$ mRNA levels in female and male BAT tissues. $(n=4-7$ per group). The female /roxp group is represented with black bar/circle dots, the female IrKOGFAP group with dark grey bar/triangle dots, the male Irloxp group with black bar/circle dots and the male IrKOGFAP group with dark grey bar/triangle dots. Values are expressed as means \pm S.E.M. ${ }^{*} P<0.0332$, $* \star P<0.0021, * * * P<0.0002, * * * * P<0.0001$ by two-way ANOVA and Tukey post-hoc test relative to IrKOGFAP vs Irloxp groups.

a normal body temperature at temperatures below thermoneutrality or to reduce metabolic rate (Humphries et al. 2003, Swoap 2008). Defense of a chronically lower body temperature set point can conserve energy.

Descending pathways from thermoregulatory centers in the hypothalamus and hindbrain regulate sympathetic neural outflow to BAT to control heat production. The median preoptic nucleus (MnPO) and the medial preoptic area (POA), containing warm-sensitive neurons, were originally recognized as playing a critical role for eliciting fever (Cooper et al. 1967, Lazarus et al. 2007, Morrison et al. 2008, Nakamura \& Morrison 2008, Romanovsky et al. 2009). They have reciprocal connections with the OVLT, a structure at the anterior wall of the third ventricle that senses circulating pyrogens (Blatteis 1992, Ott et al. 2010). Neurons in the preoptic hypothalamus are believed to provide a tonic inhibitory GABAergic
TH-IHC
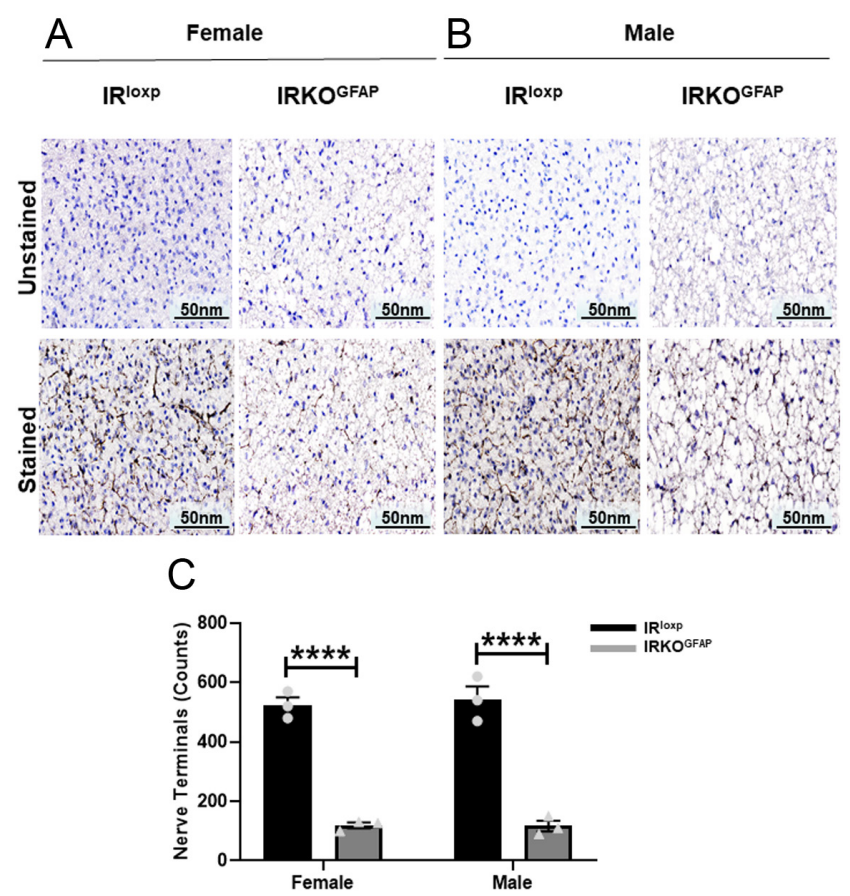

Figure 7

IrKOGFAP mice show less innervation of BAT tissue at 9-10 months of age. ( $A$ and $B$ ) Representative images of immunohistochemical (IHC) sections of unstained and stained tyrosine hydroxylase (TH) in BAT tissues of females and males. (C) Quantitative analysis of positive nerve terminals in

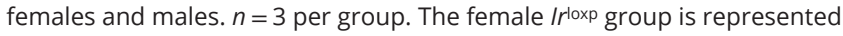
with a black bar/circle dots, the female IrKOGFAP group with dark a grey bar/triangle dots, the male /rloxp group with a black bar/circle dots and the male IrKOGFAP group with a dark grey bar/triangle dots. Values are expressed as means \pm S.E.M. $* P<0.0332, * \star P<0.0021, * \star \star P<0.0002$, $\star \star \star \star P<0.0001$ by two-way ANOVA and Tukey post-hoc test relative to IrKOGFAP vs Irloxp groups.

input to thermogenic pre-sympathetic neurons in the rostral medullary raphe nucleus (RMR) of the brain stem. In addition to the direct inhibitory projection from the preoptic hypothalamus to the RMR, this structure also receives input from the preoptic hypothalamus via a relay in the dorsomedial hypothalamus (DMH). The input from the DMH is excitatory, though still under inhibitory control from the preoptic hypothalamus (Nakamura et al. 2005). The DMH is a critical node for cold induced thermogenesis (Almeida et al. 2006); thermogenesis through sympathetic activation of BAT requires the disinhibition of the projection to the RMR from the DMH (Rathner et al. 2008). Shivering thermogenesis may also be mediated by this pathway (Nakamura \& Morrison 2011). Other hypothalamic regions, including the $\mathrm{VMH}$, LHA, PVH, and arcuate (via projections to the PVH), also modify the sympathetic activation of thermogenesis in BAT and BeAT (Fuller et al. 1975, Holt et al. 1987, 
bAR3-IHC

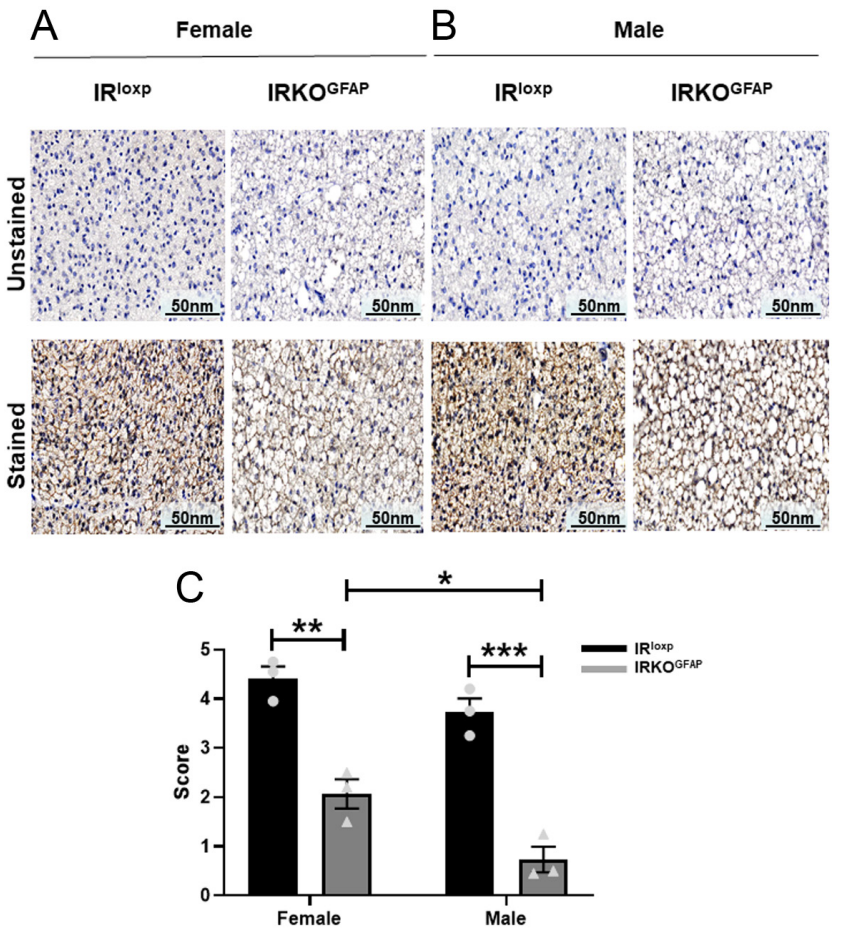

Figure 8

At 9-10 months of age, IrKOGFAP mice show lower B-adrenergic receptor 3 levels in BAT tissues. (A and B) Representative images of immunohistochemical (IHC) sections of unstained and stained BAR3 density of BAT tissues in females and males. (C) Quantification of the density of browning with a score from 1 (lowest intensity) to 5 (highest intensity) in female and male mice. $n=3$ per group. The female $/$ rloxp group is represented with a black bar/circle dots, the female IrKOGFAP group with a dark grey bar/triangle dots, the male /rloxp group with a black bar/circle dots and the male IrKOGFAP group with a dark grey bar/triangle dots. Values are expressed as means \pm S.E.M. $* P<0.0332, * * P<0.0021$, $\star \star \star P<0.0002, * \star * \star P<0.0001$ by two-way ANOVA and Tukey post-hoc test relative to IrKOGFAP vs Irloxp groups.

Amir \& Schiavetto 1990, Monda et al. 1997, Lage et al. 2016, Contreras et al. 2017).

Insulin is known to play a role in the neuronal control of body temperature (Sanchez-Alavez et al. 2010, Chong et al. 2015). Insulin can cause hyperthermia by direct inhibition of warm-sensitive neurons in the POA (Sanchez-Alavez et al. 2010). However, a role for astrocyte insulin sensing has not been previously identified. Previous work has shown that insulin signaling in astrocytes regulates GLUT-1 expression, the number and/or length of astrocyte processes throughout the brain, and the activation and synaptic contacts of neurons in the arcuate nucleus (Garcia-Caceres et al. 2016, Salameh et al. 2016). In addition, insulin signaling in astrocytes has been shown to increase exocytosis of ATP from astrocytes, which can alter the function of adjacent neurons
(Cai et al. 2018). Through such means, insulin responsive astrocytes in the vicinity of thermogenic circuits may help those neurons respond in a metabolically appropriate manner.

In IrKOGFAP mice, regulation of basal body temperature was disturbed when the mice were awake, the time period during which feeding and other activity occurs. The drop of body temperature during their period of highest physical activity is surprising. Insulin is known to affect postprandial thermogenesis; intranasal insulin administration in humans enhances the acute thermoregulatory response to food intake (Benedict et al. 2011). However, the basal body temperature of IrKOGFAP mice was 1-2 degrees lower under the darkness phase in fed conditions as well as overnight fasted conditions. The latter finding argues against an alteration in postprandial heat generation accounting for the difference in temperature.

It is also possible that insulin action in astrocytes of the blood-brain barrier underlies the alteration in body temperature in this model. Others have demonstrated a lower availability of glucose to hypothalamic neurons in IrKOGFAP mice due to reduced glucose transport into the brain (Garcia-Caceres et al. 2016, Cai et al. 2018). Increased glucose demand by neurons in the awake animal (Thomas et al. 2000) may result in insufficient local glucose availability to hypothalamic neurons for efficient body temperature regulation. If so, one would expect that mouse lines lacking astrocyte Ir expression only in adulthood would share this phenotype. While body temperature does not appear to have been directly measured in such mice, they reportedly show normal energy expenditure (Cai et al. 2018), contrary to predictions if body heat were affected. The contrasting finding of lower energy expenditure in IrKO ${ }^{\text {GFAP }}$ male mice in the current study suggests that the absence of insulin signaling in astrocytes during development leads to altered body temperature circuitry. Neuronal insulin signaling can influence neuronal survival (Mielke et al. 2006, Valenciano et al. 2006), dendritic outgrowth and arbor development (Govind et al. 2001, Cheng et al. 2003), and the maintenance of synapses (Chiu \& Cline 2010). Several Ir signaling pathways have been implicated in excitatory synaptic connectivity and dendritic structure (Wu et al. 2001, Dunah et al. 2005). Whether these processes are also modulated by insulin sensing by astrocytes is unclear but deserves attention.

Given the lack of an effect of astrocytic Ir signaling on total body weight, it is unsurprising that chronic absence of astrocyte insulin signaling driven by 
congenital expression of hGFAP-cre caused no change in body composition, locomotor activity, or food intake at 2 months of age. However, sex differences in systemic metabolism were notable. While IrKOGFAP male mice demonstrated insulin resistance at 2 months and 7 months of age, $I r \mathrm{KO}$ GFAP females did not. Instead, $I r \mathrm{KO}$ GFAP females exhibited a higher fat mass (\%) and lower lean mass (\%) at 7 months of age, accompanied by glucose intolerance. These findings suggest that these metabolic effects of insulin signaling in astrocytes are solely due to effects in the adult brain. Indeed, adult deletion of $I r$ in GFAP-expressing cells altered astrocytic morphology and circuit connectivity (Garcia-Caceres et al. 2016).

Despite a lower basal body temperature, IrKOGFAP mice exhibited a normal increase in temperature when exposed to a major cold challenge. Astrocyte populations that respond to metabolic factors are likely distinct from those involved in responding to cold conditions, similar to recent findings regarding insulin-sensing neurons. When insulin and leptin receptors are deleted from Nkx2.1positive neurons of the hypothalamus and basal ganglia, mice expend less energy, resulting in higher body weight and adiposity (Chong et al. 2015). These double knockout mice also exhibited a $1.5^{\circ} \mathrm{C}$ lower core body temperature during the fed state when housed at $20-22^{\circ} \mathrm{C}$, a mild cold stress. Further, these mice dramatically reduce their body temperature during a fast (Chong et al. 2015). At $4^{\circ} \mathrm{C}$, however, fasted mice were able to quickly increase their body temperature (Chong et al. 2015). Neurons in the midbrain and brainstem that form polysynaptic connections with BAT may be sufficient to maintain a thermogenic response to an acute cold challenge (Hermann et al. 2006, Nautiyal et al. 2008). These brain regions may differentially regulate sympathetic outflow to WAT and BAT in response to fasting and cold exposure (Bamshad et al. 1998, 1999, Brito et al. 2008, Murano et al. 2009). A recent study found a differential sympathetic drive to WAT and BAT for different lipolytic stimuli; for example, fasting altered beiging selectively in s.c. WAT without affecting BAT, an effect that was replicated by activation of AgRP neurons in the ARC (Ruan et al. 2014). In contrast, RIP-Cre neurons in VMH regulated WAT beiging and lipolysis preferentially in WAT in response to cold exposure but not fasting (Wang et al. 2018). These studies shed light on how regional neuronal circuits can tailor the modulation of body temperature to the type of stimulus received.

An important caveat for these considerations derives from the limitations of rectal probe measurement of body temperature. This procedure may be uncomfortable for the mice, and stress is known to induce vasoconstriction to maintain core body temperature (Charkoudian 2010). Repeated probe measurements in the cold challenge may, therefore, have interfered with the natural response to the low external temperature in both the experimental and control groups. Future experiments should employ intraBAT and/or intraperitoneal implanted temperature probes to examine longitudinal body temperature regulation without mouse handling.

IrKOGFAP female mice exhibited less $\mathrm{VO}_{2}$ consumption and higher RER, indicating that they utilize less fat for energy homeostasis. In male mice, an RER of around 0.87 for $I r^{\text {loxp }}$ and 0.82 for $I r K O_{\text {GFAP }}$ shows $\mathrm{CO}_{2}$ production was lowered more than $\mathrm{O}_{2}$ consumption in the $I r K O$ GFAP males. Our model exhibits that less B3-adrenergic receptor and $U_{c p} 1$ gene expression were seen in IrKOGFAP female BAT, with only a trend toward a reduction in IrKOGFAP males. These findings suggest less SNS outflow, which may increase apoptosis of adipocytes (Penicaud et al. 2000). In accord with this idea, we found that IrKOGFAP mice exhibited fewer adipocytes with bigger fat droplets in BAT. Interestingly, we found sex differences in BAT morphology. While IrKOGFAP females showed lower B3-adrenergic receptor and Ucp1 gene expression, IrKOGFAP males demonstrated higher expression of proapoptotic (Chop and Bak) genes and lower expression of anti-apoptotic $(B C l x l)$ genes. These findings support the idea that astrocyte insulin signaling affects thermogenesis by modulating SNS outflow to BAT.

Several mechanistic questions remain to be explored. Interestingly, the phenotype of IrKOGFAP mice is associated with lower $\mathrm{PGE}_{2}$ synthase in the hypothalamus (Manaserh et al. 2019), which catalyzes the conversion of prostaglandin $\mathrm{H} 2$ to $\mathrm{PGE}_{2}$. $\mathrm{PGE}_{2}$, a prostaglandin synthesized by cyclooxygenases (COX), plays a key role in regulating body temperature (Cao et al. 1997, Matsumura et al. 1997, Feleder et al. 2004). Indeed, several studies suggest astrocyte $\mathrm{PGE}_{2}$ production may influence body temperature regulation (Yun et al. 2011, Kageyama et al. 2013) by altering the function of adjacent neurons (Clasadonte et al. 2011). Previous studies in humans have shown that blockade of $\mathrm{PGE}_{2}$ production by COX inhibitors can lead to hypothermia (Donaldson \& Keatinge 1997). Overall, our findings are consistent with central insulin action regulating thermogenesis via astrocyte production of $\mathrm{PGE}_{2}$.

Notably, the POA is the site most sensitive to the pyrogenic action of $\mathrm{PGE}_{2}$ (Scammell et al. 1996, 1998) and expresses a high concentration of the $\mathrm{PGE}_{2}$ receptor $\mathrm{EP}_{3}$ (Ek et al. 2000, Oka et al. 2000, Vasilache et al. 2007). 
Administration of $\mathrm{PGE}_{2}$ into the POA of the monkey resulted in a marked and dose-dependent fever response (Onoe et al. 1992), while $\mathrm{PGE}_{2}$ injection into the POA of rats induced fever and Fos induction in the ventromedial POA and the paraventricular nucleus (PVH) (Scammell et al. 1996). In mice, low $\mathrm{PGE}_{2}$ levels in the POA can reduce body temperature (Bhatnagar et al. 1993, Yoshida et al. 2009). Preoptic neurons are silenced when $\mathrm{PGE}_{2}$ binds to $\mathrm{EP}_{3}$ receptors, hence, providing a disinhibition of $\mathrm{RMR}$ presympathetic neurons. Neurons found in the $\mathrm{MnPO}$ are responsive to the action of $\mathrm{PGE}_{2}$ and project directly to the RMR (Yoshida et al. 2009). Skin vasoconstriction due to skin cooling or $\mathrm{PGE}_{2}$ delivery to the preoptic hypothalamus depends on the inhibition of the direct projection from the POA to the RMR. Administration of $\mathrm{PGE}_{2}$ to the $\mathrm{PVH}$ also leads to the activation of BAT thermogenesis (Bhatnagar et al. 1993, Contreras et al. 2017). The POA and PVH are thus prime candidates for further investigation of the role of insulin-sensitive astrocytes in thermogenesis.

In summary, our data confirm that impaired insulin signaling in astrocytes lead to systemic insulin and glucose dysregulation largely due to actions in the adult brain. These studies have demonstrated that astrocyte insulin signaling contributes to body temperature regulation by influencing sympathetic stimulation of heat generation by BAT. It is possible that the lower production of astrocyte $\mathrm{PGE}_{2}$ synthase induced by absence of astrocytic insulin signaling contributes to dysregulation of body temperature in this model. Given that thermogenesis is a critical component of energy expenditure, our results suggest that insulin resistance in astrocytes may contribute to the development of obesity and type 2 diabetes or exacerbate these conditions when already present, providing a potential target for therapeutic strategies.

\section{Supplementary materials}

This is linked to the online version of the paper at https://doi.org/10.1530/ JOE-20-0052.

\section{Declaration of interest}

The authors declare that there is no conflict of interest that could be perceived as prejudicing the impartiality of the research reported.

\section{Funding}

This funding was supported by a grant from the National Institutes of Health (NIH R01 HD081792 to J W H).

\section{Acknowledgements}

The authors thank Andrea L Kalinoski and colleagues from The Advanced Microscopy and Imaging Center for their help with histological analysis.

\section{References}

Almeida MC, Steiner AA, Branco LGS \& Romanovsky AA 2006 Neural substrate of cold-seeking behavior in endotoxin shock. PLOS ONE $\mathbf{1}$ e1. (https://doi.org/10.1371/journal.pone.0000001)

Amir S \& Schiavetto A 1990 Injection of prostaglandin E2 into the anterior hypothalamic preoptic area activates brown adipose tissue thermogenesis in the rat. Brain Research 528 138-142. (https://doi. org/10.1016/0006-8993(90)90206-q)

Araque A, Parpura V, Sanzgiri RP \& Haydon PG 1999 Tripartite synapses: glia, the unacknowledged partner. Trends in Neurosciences 22 208-215. (https://doi.org/10.1016/s0166-2236(98)01349-6)

Bamshad M, Aoki VT, Adkison MG, Warren WS \& Bartness TJ 1998 Central nervous system origins of the sympathetic nervous system outflow to white adipose tissue. American Journal of Physiology $\mathbf{2 7 5}$ R291-R299. (https://doi.org/10.1152/ajpregu.1998.275.1.R291)

Bamshad M, Song CK \& Bartness TJ 1999 CNS origins of the sympathetic nervous system outflow to brown adipose tissue. American Journal of Physiology 276 R1569-R1578. (https://doi.org/10.1152/ ajpregu.1999.276.6.R1569)

Benedict C, Brede S, Schioth HB, Lehnert H, Schultes B, Born J \& Hallschmid M 2011 Intranasal insulin enhances postprandial thermogenesis and lowers postprandial serum insulin levels in healthy men. Diabetes 60 114-118. (https://doi.org/10.2337/db100329)

Bhatnagar S, Meaney MJ \& Amir S 1993 The effects of prostaglandin E2 injected into the paraventricular nucleus of the hypothalamus on brown adipose tissue thermogenesis in spontaneously hypertensive rats. Brain Research 613 285-287. (https://doi.org/10.1016/00068993(93)90911-6)

Blatteis CM 1992 Role of the Ovlt in the febrile response to circulating pyrogens. Progress in Brain Research 91 409-412. (https://doi. org/10.1016/s0079-6123(08)62360-2)

Brito NA, Brito MN \& Bartness TJ 2008 Differential sympathetic drive to adipose tissues after food deprivation, cold exposure or glucoprivation. American Journal of Physiology: Regulatory, Integrative and Comparative Physiology 294 R1445-R1452. (https://doi. org/10.1152/ajpregu.00068.2008)

Cai W, Xue C, Sakaguchi M, Konishi M, Shirazian A, Ferris HA, Li ME, Yu R, Kleinridders A, Pothos EN, et al. 2018 Insulin regulates astrocyte gliotransmission and modulates behavior. Journal of Clinical Investigation 128 2914-2926. (https://doi.org/10.1172/ JCI99366)

Cao C, Matsumura K, Yamagata K \& Watanabe Y 1997 Involvement of cyclooxygenase-2 in LPS-induced fever and regulation of its mRNA by LPS in the rat brain. American Journal of Physiology 272 R1712-R1725. (https://doi.org/10.1152/ajpregu.1997.272.6.R1712)

Charkoudian N 2010 Mechanisms and modifiers of reflex induced cutaneous vasodilation and vasoconstriction in humans. Journal of Applied Physiology 109 1221-1228. (https://doi.org/10.1152/ japplphysiol.00298.2010)

Chechi K, Voisine P, Mathieu P, Laplante M, Bonnet S, Picard F, Joubert P \& Richard D 2017 Functional characterization of the Ucp1-associated oxidative phenotype of human epicardial adipose tissue. Scientific Reports 7 15566. (https://doi.org/10.1038/s41598-017-15501-7)

Cheng CM, Mervis RF, Niu SL, Salem N, Witters LA, Tseng V, Reinhardt R $\&$ Bondy CA 2003 Insulin-like growth factor 1 is essential for normal dendritic growth. Journal of Neuroscience Research 73 1-9. (https://doi. org/10.1002/jnr.10634) 
Chiu SL \& Cline HT 2010 Insulin receptor signaling in the development of neuronal structure and function. Neural Development 5 7. (https:// doi.org/10.1186/1749-8104-5-7)

Chong ACN, Greendyk RA \& Zeltser LM 2015 Distinct networks of leptin- and insulin-sensing neurons regulate thermogenic responses to nutritional and cold challenges. Diabetes 64 137-146. (https://doi. org/10.2337/db14-0567)

Clasadonte J, Poulain P, Hanchate NK, Corfas G, Ojeda SR \& Prevot V 2011 Prostaglandin E2 release from astrocytes triggers gonadotropinreleasing hormone $(\mathrm{GnRH})$ neuron firing via EP2 receptor activation. PNAS 108 16104-16109. (https://doi.org/10.1073/pnas.1107533108)

Contreras C, Gonzalez F, Ferno J, Dieguez C, Rahmouni K, Nogueiras R \& Lopez M 2015 The brain and brown fat. Annals of Medicine $\mathbf{4 7}$ 150-168. (https://doi.org/10.3109/07853890.2014.919727)

Contreras C, Nogueiras R, Dieguez C, Rahmouni K \& Lopez M 2017 Traveling from the hypothalamus to the adipose tissue: the thermogenic pathway. Redox Biology 12 854-863. (https://doi. org/10.1016/j.redox.2017.04.019)

Cooper KE, Cranston WI \& Honour AJ 1967 Observations on the site and mode of action of pyrogens in the rabbit brain. Journal of Physiology 191 325-337. (https://doi.org/10.1113/jphysiol.1967. sp008253)

Daubner SC, Le T \& Wang S 2011 Tyrosine hydroxylase and regulation of dopamine synthesis. Archives of Biochemistry and Biophysics 508 1-12. (https://doi.org/10.1016/j.abb.2010.12.017)

Donaldson GC \& Keatinge WR 1997 Mortality related to cold weather in elderly people in southeast England, 1979-1994. BMJ 315 1055-1056. (https://doi.org/10.1136/bmj.315.7115.1055)

Dunah AW, Hueske E, Wyszynski M, Hoogenraad CC, Jaworski J, Pak DT, Simonetta A, Liu G \& Sheng M 2005 LAR receptor protein tyrosine phosphatases in the development and maintenance of excitatory synapses. Nature Neuroscience 8 458-467. (https://doi.org/10.1038/ nn1416)

Ek M, Arias C, Sawchenko P \& Ericsson-Dahlstrand A 2000 Distribution of the EP3 prostaglandin E-2 receptor subtype in the rat brain: relationship to sites of interleukin-1-induced cellular responsiveness. Journal of Comparative Neurology 428 5-20. (https://doi. org/10.1002/1096-9861(20001204)428:1<5::aid-cne2>3.0.co;2-m)

Feldmann HM, Golozoubova V, Cannon B \& Nedergaard J 2009 UCP1 ablation induces obesity and abolishes diet-induced thermogenesis in mice exempt from thermal stress by living at thermoneutrality. Cell Metabolism 9 203-209. (https://doi.org/10.1016/j.cmet.2008.12.014)

Feleder C, Perlik V \& Blatteis CM 2004 Preoptic alpha 1- and alpha 2-noradrenergic agonists induce, respectively, PGE2-independent and PGE2-dependent hyperthermic responses in guinea pigs. American Journal of Physiology: Regulatory, Integrative and Comparative Physiology 286 R1156-R1166. (https://doi.org/10.1152/ajpregu.00486.2003)

Fraulob JC, Ogg-Diamantino R, Fernandes-Santos C, Aguila MB \& Mandarim-De-Lacerda CA 2010 A mouse model of metabolic syndrome: insulin resistance, fatty liver and non-alcoholic fatty pancreas disease (NAFPD) in C57BL/6 mice fed a high fat diet. Journal of Clinical Biochemistry and Nutrition 46 212-223. (https://doi. org/10.3164/jcbn.09-83)

Fuller CA, Horwitz BA \& Horowitz JM 1975 Shivering and nonshivering thermogenic responses of cold-exposed rats to hypothalamic warming. American Journal of Physiology 228 1519-1524. (https://doi. org/10.1152/ajplegacy.1975.228.5.1519)

Garcia-Caceres C, Quarta C, Varela L, Gao Y, Gruber T, Legutko B, Jastroch M, Johansson P, Ninkovic J, Yi CX, et al. 2016 Astrocytic insulin signaling couples brain glucose uptake with nutrient availability. Cell 166 867-880. (https://doi.org/10.1016/j. cell.2016.07.028)

Ghadieh HE, Smiley ZN, Kopfman MW, Najjar MG, Hake MJ \& Najjar SM 2015 Chlorogenic acid/chromium supplement rescues diet-induced insulin resistance and obesity in mice. Nutrition and Metabolism 1219. (https://doi.org/10.1186/s12986-015-0014-5)
Govind S, Kozma R, Monfries C, Lim L \& Ahmed S 2001 Cdc42Hs facilitates cytoskeletal reorganization and neurite outgrowth by localizing the $58-\mathrm{kD}$ insulin receptor substrate to filamentous actin. Journal of Cell Biology 152 579-594. (https://doi.org/10.1083/ jcb.152.3.579)

Harms M \& Seale P 2013 Brown and beige fat: development, function and therapeutic potential. Nature Medicine 19 1252-1263. (https://doi. org $/ 10.1038 / \mathrm{nm} .3361)$

Heeren J \& Munzberg H 2013 Novel aspects of brown adipose tissue biology. Endocrinology and Metabolism Clinics of North America 42 89-107. (https://doi.org/10.1016/j.ecl.2012.11.004)

Heinrich G, Russo L, Castaneda TR, Pfeiffer V, Ghadieh HE, Ghanem SS, Wu J, Faulkner LD, Ergun S, Mcinerney MF, et al. 2016 Leptin resistance contributes to obesity in mice with null mutation of carcinoembryonic antigen-related cell adhesion molecule 1. Journal of Biological Chemistry 291 11124-11132. (https://doi.org/10.1074/jbc. M116.716431)

Hermann GE, Barnes MJ \& Rogers RC 2006 Leptin and thyrotropinreleasing hormone: cooperative action in the hindbrain to activate brown adipose thermogenesis. Brain Research 1117 118-124. (https:// doi.org/10.1016/j.brainres.2006.08.018)

Holt SJ, Wheal HV \& York DA 1987 Hypothalamic control of brown adipose tissue in Zucker lean and obese rats. Effect of electrical stimulation of the ventromedial nucleus and other hypothalamic centres. Brain Research 405 227-233. (https://doi.org/10.1016/00068993(87)90292-7)

Humphries MM, Thomas DW \& Kramer DL 2003 The role of energy availability in Mammalian hibernation: a cost-benefit approach. Physiological and Biochemical Zoology 76 165-179. (https://doi. org/10.1086/367950)

Kageyama H, Endo K, Osaka T, Watanabe J, Wang LH, Ito K, Suzuki M, Sakagami J, Takenoya F \& Shioda S 2013 Galanin-like peptide (GALP) facilitates thermogenesis via synthesis of prostaglandin E2 by astrocytes in the periventricular zone of the third ventricle. Journal of Molecular Neuroscience 50 443-452. (https://doi.org/10.1007/s12031013-9952-4)

Kim JG, Suyama S, Koch M, Jin S, Argente-Arizon P, Argente J, Liu ZW, Zimmer MR, Jeong JK, Szigeti-Buck K, et al. 2014 Leptin signaling in astrocytes regulates hypothalamic neuronal circuits and feeding. Nature Neuroscience 17 908-910. (https://doi.org/10.1038/nn.3725)

Könner AC, Janoschek R, Plum L, Jordan SD, Rother E, Ma X, Xu C, Enriori P, Hampel B, Barsh GS, et al. 2007 Insulin action in AgRPexpressing neurons is required for suppression of hepatic glucose production. Cell Metabolism 5 438-449. (https://doi.org/10.1016/j. cmet.2007.05.004)

Lage R, Ferno J, Nogueiras R, Dieguez C \& Lopez M 2016 Contribution of adaptive thermogenesis to the hypothalamic regulation of energy balance. Biochemical Journal 473 4063-4082. (https://doi.org/10.1042/ BCJ20160012)

Lazarus M, Yoshida K, Coppari R, Bass CE, Mochizuki T, Lowell BB \& Saper CB 2007 EP3 prostaglandin receptors in the median preoptic nucleus are critical for fever responses. Nature Neuroscience $\mathbf{1 0}$ 1131-1133. (https://doi.org/10.1038/nn1949)

Lee P, Werner CD, Kebebew E \& Celi FS 2014 Functional thermogenic beige adipogenesis is inducible in human neck fat. International Journal of Obesity 38 170-176. (https://doi.org/10.1038/ijo.2013.82)

Lidell ME, Betz MJ, Dahlqvist Leinhard O, Heglind M, Elander L, Slawik M, Mussack T, Nilsson D, Romu T, Nuutila P, et al. 2013 Evidence for two types of brown adipose tissue in humans. Nature Medicine 19 631-634. (https://doi.org/10.1038/nm.3017)

Manaserh IH, Chikkamenahalli L, Ravi S, Dube PR, Park JJ \& Hill JW 2019 Ablating astrocyte insulin receptors leads to delayed puberty and hypogonadism in mice. PLoS Biology 17 e3000189. (https://doi. org/10.1371/journal.pbio.3000189)

Matsumura K, Cao C \& Watanabe Y 1997 Possible role of cyclooxygenase- 2 in the brain vasculature in febrile response. https://joe.bioscientifica.com

https://doi.org/10.1530/JOE-20-0052 (c) 2020 Society for Endocrinology Published by Bioscientifica Ltd. Printed in Great Britain 
Annals of the New York Academy of Sciences 813 302-306. (https://doi. org/10.1111/j.1749-6632.1997.tb51709.x)

Mehlem A, Hagberg CE, Muhl L, Eriksson U \& Falkevall A 2013 Imaging of neutral lipids by oil red $\mathrm{O}$ for analyzing the metabolic status in health and disease. Nature Protocols 8 1149-1154. (https://doi. org/10.1038/nprot.2013.055)

Middeldorp J \& Hol EM 2011 GFAP in health and disease. Progress in Neurobiology 93 421-443. (https://doi.org/10.1016/j. pneurobio.2011.01.005)

Mielke JG, Taghibiglou C \& Wang YT 2006 Endogenous insulin signaling protects cultured neurons from oxygen-glucose deprivation-induced cell death. Neuroscience 143 165-173. (https://doi.org/10.1016/j. neuroscience.2006.07.055)

Mikaeili F, Kia EB, Sharbatkhori M, Sharifdini M, Jalalizand N, Heidari Z, Zarei Z, Stensvold CR \& Mirhendi H 2013 Comparison of six simple methods for extracting ribosomal and mitochondrial DNA from Toxocara and Toxascaris nematodes. Experimental Parasitology 134 155-159. (https://doi.org/10.1016/i.exppara.2013.02.008)

Monda M, Sullo A, De Luca V, Viggiano A \& Pellicano MP 1997 Acute lesions of the ventromedial hypothalamus reduce sympathetic activation and thermogenic changes induced by PGE1. Journal of Physiology 91 285-290. (https://doi.org/10.1016/s09284257(97)82408-4)

Morrison SF, Nakamura K \& Madden CJ 2008 Central control of thermogenesis in mammals. Experimental Physiology 93 773-797. (https://doi.org/10.1113/expphysiol.2007.041848)

Murano I, Barbatelli G, Giordano A \& Cinti S 2009 Noradrenergic parenchymal nerve fiber branching after cold acclimatisation correlates with brown adipocyte density in mouse adipose organ. Journal of Anatomy 214 171-178. (https://doi.org/10.1111/j.14697580.2008.01001.x)

Nakamura K \& Morrison SF 2008 A thermosensory pathway that controls body temperature. Nature Neuroscience 11 62-71. (https://doi. org/10.1038/nn2027)

Nakamura K \& Morrison SF 2011 Central efferent pathways for colddefensive and febrile shivering. Journal of Physiology 589 3641-3658. (https://doi.org/10.1113/jphysiol.2011.210047)

Nakamura Y, Nakamura K, Matsumura K, Kobayashi S, Kaneko T \& Morrison SF 2005 Direct pyrogenic input from prostaglandin EP3 receptor-expressing preoptic neurons to the dorsomedial hypothalamus. European Journal of Neuroscience 22 3137-3146. (https://doi.org/10.1111/j.1460-9568.2005.04515.x)

Nautiyal KM, Dailey M, Brito N, Brito MN, Harris RB, Bartness TJ \& Grill HJ 2008 Energetic responses to cold temperatures in rats lacking forebrain-caudal brain stem connections. American Journal of Physiology: Regulatory, Integrative and Comparative Physiology 295 R789-R798. (https://doi.org/10.1152/ajpregu.90394.2008)

Nobili A, Latagliata EC, Viscomi MT, Cavallucci V, Cutuli D, Giacovazzo G, Krashia P, Rizzo FR, Marino R, Federici M, et al. 2017 Dopamine neuronal loss contributes to memory and reward dysfunction in a model of Alzheimer's disease. Nature Communications 8 14727. (https://doi.org/10.1038/ncomms14727)

Oelkrug R, Polymeropoulos ET \& Jastroch M 2015 Brown adipose tissue: physiological function and evolutionary significance. Journal of Comparative Physiology: B, Biochemical, Systemic, and Environmental Physiology 185 587-606. (https://doi.org/10.1007/s00360-015-0907-7)

Oka T, Oka K, Scammell TE, Lee C, Kelly JF, Nantel F, Elmquist JK \& Saper CB 2000 Relationship of EP(1-4) prostaglandin receptors with rat hypothalamic cell groups involved in lipopolysaccharide fever responses. Journal of Comparative Neurology 428 20-32. (https://doi. org/10.1002/1096-9861(20001204)428:1<20::aid-cne3>3.0.co;2-x)

Onoe H, Watanabe Y, Ono K, Koyama Y \& Hayaishi O 1992 Prostaglandin-E(2) exerts an awakening effect in the posterior hypothalamus at a site distinct from that mediating its febrile action in the anterior hypothalamus. Journal of Neuroscience 12 2715-2725. (https://doi.org/10.1523/JNEUROSCI.12-07-02715.1992)
Ott D, Murgott J, Rafalzik S, Wuchert F, Schmalenbeck B, Roth J \& Gerstberger R 2010 Neurons and glial cells of the rat organum vasculosum laminae terminalis directly respond to lipopolysaccharide and pyrogenic cytokines. Brain Research 1363 93-106. (https://doi. org/10.1016/j.brainres.2010.09.083)

Penicaud L, Cousin B, Leloup C, Lorsignol A \& Casteilla L 2000 The autonomic nervous system, adipose tissue plasticity, and energy balance. Nutrition 16 903-908. (https://doi.org/10.1016/s08999007(00)00427-5)

Perea G, Navarrete M \& Araque A 2009 Tripartite synapses: astrocytes process and control synaptic information. Trends in Neurosciences 32 421-431. (https://doi.org/10.1016/j.tins.2009.05.001)

Qiu X, Dowling AR, Marino JS, Faulkner LD, Bryant B, Bruning JC, Elias CF \& Hill JW 2013 Delayed puberty but normal fertility in mice with selective deletion of insulin receptors from kiss1 cells. Endocrinology 154 1337-1348. (https://doi.org/10.1210/en.20122056)

Rathner JA, Madden CJ \& Morrison SF 2008 Central pathway for spontaneous and prostaglandin E2-evoked cutaneous vasoconstriction. American Journal of Physiology: Regulatory, Integrative and Comparative Physiology 295 R343-R354. (https://doi.org/10.1152/ ajpregu.00115.2008)

Reeves SA, Helman LJ, Allison A \& Israel MA 1989 Molecular cloning and primary structure of human glial fibrillary acidic protein. PNAS $\mathbf{8 6}$ 5178-5182. (https://doi.org/10.1073/pnas.86.13.5178)

Romanovsky AA, Almeida MC, Garami A, Steiner AA, Norman MH, Morrison SF, Nakamura K, Burmeister JJ \& Nucci TB 2009 The transient receptor potential vanilloid-1 channel in thermoregulation: a thermosensor it is not. Pharmacological Reviews 61 228-261. (https:// doi.org/10.1124/pr.109.001263)

Ruan HB, Dietrich MO, Liu ZW, Zimmer MR, Li MD, Singh JP, Zhang K, Yin R, Wu J, Horvath TL, et al. 2014 O-GlcNAc transferase enables AgRP neurons to suppress browning of white fat. Cell 159 306-317. (https://doi.org/10.1016/j.cell.2014.09.010)

Salameh TS, Shah GN, Price TO, Hayden MR \& Banks WA 2016 Bloodbrain barrier disruption and neurovascular Unit Dysfunction in diabetic mice: protection with the mitochondrial carbonic anhydrase inhibitor topiramate. Journal of Pharmacology and Experimental Therapeutics 359 452-459. (https://doi.org/10.1124/ jpet.116.237057)

Sanchez-Alavez M, Tabarean IV, Osborn O, Mitsukawa K, Schaefer J, Dubins J, Holmberg KH, Klein I, Klaus J, Gomez LF, et al. 2010 Insulin causes hyperthermia by direct inhibition of warm-sensitive neurons. Diabetes 59 43-50. (https://doi.org/10.2337/db09-1128)

Scammell TE, Elmquist JK, Griffin JD \& Saper CB 1996 Ventromedial preoptic prostaglandin $\mathrm{E} 2$ activates fever-producing autonomic pathways. Journal of Neuroscience 16 6246-6254. (https://doi. org/10.1523/JNEUROSCI.16-19-06246.1996)

Scammell TE, Griffin JD, Elmquist JK \& Saper CB 1998 Microinjection of a cyclooxygenase inhibitor into the anteroventral preoptic region attenuates LPS fever. American Journal of Physiology 274 R783-R789. (https://doi.org/10.1152/ajpregu.1998.274.3.R783)

Schulz TJ, Huang TL, Tran TT, Zhang H, Townsend KL, Shadrach JL, Cerletti M, Mcdougall LE, Giorgadze N, Tchkonia T, et al. 2011 Identification of inducible brown adipocyte progenitors residing in skeletal muscle and white fat. PNAS 108 143-148. (https://doi. org/10.1073/pnas.1010929108)

Shiow LR, Favrais G, Schirmer L, Schang AL, Cipriani S, Andres C, Wright JN, Nobuta H, Fleiss B, Gressens P, et al. 2017 Reactive astrocyte COX2-PGE2 production inhibits oligodendrocyte maturation in neonatal white matter injury. Glia 65 2024-2037. (https://doi.org/10.1002/glia.23212)

Solanki S, Dube PR, Birnbaumer L \& Vazquez G 2017 Reduced necrosis and content of apoptotic M1 macrophages in advanced atherosclerotic plaques of mice With macrophage-specific loss of Trpc3. Scientific Reports 7 42526. (https://doi.org/10.1038/srep42526) https://joe.bioscientifica.com

https://doi.org/10.1530/JOE-20-0052 (c) 2020 Society for Endocrinology Published by Bioscientifica Ltd. Printed in Great Britain 
Swoap SJ 2008 The pharmacology and molecular mechanisms underlying temperature regulation and torpor. Biochemical Pharmacology 76 817-824. (https://doi.org/10.1016/j.bcp.2008.06.017)

Thomas M, Sing H, Belenky G, Holcomb H, Mayberg H, Dannals R, Wagner H, Thorne D, Popp K, Rowland L, et al. 2000 Neural basis of alertness and cognitive performance impairments during sleepiness. I. Effects of $24 \mathrm{~h}$ of sleep deprivation on waking human regional brain activity. Journal of Sleep Research 9 335-352. (https://doi.org/10.1046/ j.1365-2869.2000.00225.x)

Valenciano AI, Corrochano S, De Pablo F, De La Villa P \& De La Rosa EJ 2006 Proinsulin/insulin is synthesized locally and prevents caspaseand cathepsin-mediated cell death in the embryonic mouse retina. Journal of Neurochemistry 99 524-536. (https://doi.org/10.1111/j.14714159.2006.04043.x)

Vasilache AM, Andersson J \& Nilsberth C 2007 Expression of PGE(2) EP3 receptor subtypes in the mouse preoptic region. Neuroscience Letters 423 179-183. (https://doi.org/10.1016/j.neulet.2007.06.048)

Virtanen KA, Lidell ME, Orava J, Heglind M, Westergren R, Niemi T, Taittonen M, Laine J, Savisto NJ, Enerback S, et al. 2009 Functional brown adipose tissue in healthy adults. New England Journal of Medicine 360 1518-1525. (https://doi.org/10.1056/NEJMoa0808949)

Vosselman MJ, Brans B, Van Der Lans AA, Wierts R, Van Baak MA, Mottaghy FM, Schrauwen P \& Van Marken Lichtenbelt WD 2013 Brown adipose tissue activity after a high-calorie meal in humans. American Journal of Clinical Nutrition 98 57-64. (https://doi. org/10.3945/ajcn.113.059022)
Wang Y, Hsuchou H, He Y, Kastin AJ \& Pan W 2015 Role of astrocytes in leptin signaling. Journal of Molecular Neuroscience 56 829-839. (https:// doi.org/10.1007/s12031-015-0518-5)

Wang B, Li A, Li X, Ho PW, Wu D, Wang X, Liu Z, Wu KK, Yau SS, Xu A, et al. 2018 Activation of hypothalamic RIP-Cre neurons promotes beiging of WAT via sympathetic nervous system. EMBO Reports 19 e44977. (https://doi.org/10.15252/embr.201744977)

Wu GY, Deisseroth K \& Tsien RW 2001 Spaced stimuli stabilize MAPK pathway activation and its effects on dendritic morphology. Nature Neuroscience 4 151-158. (https://doi.org/10.1038/83976)

Xu J, Chalimoniuk M, Shu Y, Simonyi A, Sun AY, Gonzalez FA, Weisman GA, Wood WG \& Sun GY 2003 Prostaglandin E2 production in astrocytes: regulation by cytokines, extracellular ATP, and oxidative agents. Prostaglandins, Leukotrienes, and Essential Fatty Acids 69 437-448. (https://doi.org/10.1016/j.plefa.2003.08.016)

Yang L, Qi Y \& Yang Y 2015 Astrocytes control food intake by inhibiting AGRP neuron activity via adenosine A1 receptors. Cell Reports 11 798-807. (https://doi.org/10.1016/j.celrep.2015.04.002)

Yoshida K, Li XD, Cano G, Lazarus M \& Saper CB 2009 Parallel preoptic pathways for thermoregulation. Journal of Neuroscience 29 11954-11964. (https://doi.org/10.1523/ JNEUROSCI.2643-09.2009)

Yun CH, Kim JG, Park BS, Lee HM, Kim DH, Kim EO, Park JJ, Park JW, Damante G, Kim YI, et al. 2011 TTF-1 action on the transcriptional regulation of cyclooxygenase-2 gene in the rat brain. PLOS ONE 6 e28959. (https://doi.org/10.1371/journal.pone.0028959)

Received in final form 3 July 2020

Accepted 13 July 2020

Accepted Manuscript published online 13 July 2020 (c) 2020 Society for Endocrinology Published by Bioscientifica Ltd. 